\title{
Epidemiology of injuries in Olympic-style karate competitions: systematic review and meta-analysis
}

\author{
Reidar P Lystad (D) ,' Dusana Augustovičová, ${ }^{2}$ Gail Harris, ${ }^{1}$ Kirran Beskin, ${ }^{1}$ \\ Rafael Arriaza 3,4
}

- Additional material is

published online only. To view please visit the journal online (http://dx.doi.org/10.1136/ bjsports-2020-101990).

${ }^{1}$ Australian Institute of Health Innovation, Macquarie University, Sydney, New South Wales, Australia

${ }^{2}$ Faculty of Physical Education and Sports, Comenius

University, Bratislava, Slovakia ${ }^{3}$ Instituto Médico Arriaza y

Asociados, La Coruña, La Coruña, Spain

${ }^{4}$ Physical Education and Sports School, Universidade da Coruña, A Coruña, Spain

Correspondence to Dr Reidar P Lystad, Australian Institute of Health Innovation, Macquarie University, Sydney, New South Wales, Australia; reidar.lystad@mq.edu.au

Accepted 27 June 2020
Check for updates

(C) Author(s) (or their employer(s)) 2020. No commercial re-use. See rights and permissions. Published by BMJ.

To cite: Lystad RP Augustovičová $D$, Harris $G$, et al. Br J Sports Med 2020;54:976-983.

\section{ABSTRACT \\ Objective To report the epidemiology of injuries in \\ Olympic-style karate competitions.}

Design Systematic review and meta-analysis. Pooled estimates of injury incidence rates per 1000 athleteexposures (IIR $\left.\mathrm{R}_{\mathrm{AE}}\right)$ and per 1000 min of exposure $\left(I I R_{\mathrm{ME}}\right)$ were obtained by fitting random-effects models.

Data sources MEDLINE, Embase, AMED, SPORTDiscus and AusportMed databases were searched from inception to 21 August 2019.

Eligibility criteria Prospective cohort studies published in peer-reviewed journals and reporting injury data (ie, incidence, severity, location, type, mechanism or risk factors) among athletes participating in Olympicstyle karate competition.

Results Twenty-eight studies were included. The estimated IIR and IIR $\mathrm{R}_{\mathrm{ME}}$ were $88.3(95 \% \mathrm{Cl} 66.6$ to $117.2)$ and $39.2(95 \% \mathrm{Cl} 30.6$ to 50.2$)$, respectively. The most commonly injured body region was the head and neck (median: $57.9 \%$; range: $33.3 \%$ to $96.8 \%$ ), while contusion (median: $68.3 \%$; range: $54.9 \%$ to $95.1 \%$ ) and laceration (median: $18.6 \%$; range: $0.0 \%$ to $29.3 \%$ ) were the most frequently reported types of injury. Despite inconsistency in classifying injury severity, included studies reported that most injuries were in the least severe category. There was no significant difference in $\| \mathrm{R}_{\mathrm{ME}}$ between male and female karate athletes (rate ratio $1.09 ; 95 \% \mathrm{Cl} 0.88$ to 1.36 ).

Conclusion Karate athletes sustain, on average, 1 injury every 11 exposures (bouts) or approximately 25 min of competition. The large majority of these injuries were minor or mild in severity.

\section{INTRODUCTION}

Karate is a popular martial art and combat sport originating from Okinawa, Japan. ${ }^{1}$ The World Karate Federation (WKF), which is recognised by the IOC, is the largest international governing body for the sport karate with an estimated 100 million athletes from 199 member countries. ${ }^{2}$ The sport will make its debut appearance on the official Olympic Games programme at Tokyo 2020 (postponed to July to August 2021). ${ }^{13}$

Sport karate competition has two modalities: sparring (kumite) and forms (kata). ${ }^{4}$ This review is focused on Olympic-style karate kumite competition. Kumite competition is divided into individual and team competitions. In individual contests athletes of similar weight compete against each other in specified weight categories, whereas in team contests athletes compete without any weight category restrictions. The tournament format of both individual and team competitions is typically direct elimination with repechage (ie, a system whereby competitors who lose to pool winners enter into a secondary championship bracket and compete for third place). The current WKF kumite competition rules allow sweeps and throws, as well as strikes using light contact to the trunk and head regions. ${ }^{4}$ The most dangerous techniques are banned (eg, strikes to the throat; strikes using the head, knees or elbows; and throws over the shoulder). All permissible techniques must be delivered with good control and good form to be awarded points. The scoring system is as follows: kicks to the head and throws followed by a strike are awarded 3 points (ippon), kicks to the trunk are awarded 2 points (wazari) and punches to the head and trunk are awarded 1 point $(y u k o)$. Kumite contestants are required to wear WKF-approved protective equipment such as body protector (plus chest protector for female athletes), mouthguard, hand protectors (mitts) and shin and foot protectors. ${ }^{4}$

In a 2013 review of 20 karate injury epidemiology studies, the injury incidence rates per 1000 athleteexposures (IIR $\mathrm{AE}_{\mathrm{AE}}$ ) ranged from 11.3 to 194.0.5 This narrative review did not include all relevant prospective cohort studies that were available, nor did it assess the risk of bias of included studies, evaluate injury severity or provide any quantitative synthesis of injury incidence data. In September 2018, Thomas and Ornstein ${ }^{6}$ published a systematic review of injuries in karate, which included case reports, cross-sectional surveys and retrospective and prospective cohort studies. This review was limited because: (1) at least three prospective cohort studies published in non-English languages were omitted $;^{7-9}(2)$ it did not distinguish between Olympic-style (ie, WKF style) and other forms of karate; (3) it included non-peer reviewed data (eg, unpublished dissertation and conference abstracts); (4) it did not correctly identify all duplicate datasets; and (5) it provided no overall quantitative synthesis of injury incidence or risk factor data.

We flag that karate competition rules have changed over time. For instance, in 2000 the WKF changed the rules to make karate competitions more dynamic and attractive and to increase safety. Major changes were introduced to the scoring system, the range of permissible techniques was revised and the degree of contact to the head was restricted. In 2009 , the scoring system was simplified, additional techniques were prohibited and new protective equipment was introduced for younger athletes (ie, face mask and body protector).

We aimed to provide a comprehensive and highquality overview of the epidemiology of injuries 
in Olympic-style karate competitions. Specifically, the primary objective was to determine the injury incidence rate. The secondary objectives were to describe the distribution of injuries by body location, type of injury, mechanism injury and injury severity; to identify risk factors of injury (eg, sex, age and rule changes), including production of quantitative summary estimates of effect sizes, where appropriate; and to compare the injury incidence rates across three time periods (ie, before 2000, during 2000-2008 and after 2008).

\section{METHODS}

\section{Protocol and registration}

The protocol for this systematic review and meta-analysis was registered with the international prospective register of systematic reviews (PROSPERO) in June 2018 (registration number CRD42018096496). The reporting of this systematic review and meta-analysis adhered to the Preferred Reporting Items for Systematic Reviews and Meta-Analyses Statement guidelines. ${ }^{10}$

\section{Eligibility criteria}

Cohort studies reporting on prospectively collected injury data and published in peer-reviewed literature were eligible for inclusion in this systematic review. Retrospective cohort studies, cross-sectional studies, case-control studies, case reports, case series, commentaries, editorials, letters to the editor and literature reviews were not eligible for inclusion in this review. No language restrictions were applied. Eligible studies had to report injury incidence data from injury surveillance of medical attention injuries sustained by athletes participating in Olympic-style karate kumite competition. For the purposes of this review, only studies featuring karate athletes competing in tournaments organised by the WKF or its precursor, World Union of Karate-do Organizations, or their affiliates, were eligible for inclusion. No studies were excluded based on sex, age or any other characteristics of the study population.

\section{Information sources and search strategy}

A comprehensive search of the literature was undertaken. This included electronic searching of the MEDLINE, Embase, AMED, SPORTDiscus and AusportMed databases from inception to 21 August 2019, without any limitations based on language of publication, study setting, geographical location or publication date. MEDLINE, Embase and AMED were searched via the Ovid SP portal, while SPORTDiscus and AusportMed were accessed via the EBSCOhost and Informit portals, respectively. In addition to the electronic database searching, the bibliographies of the included studies and relevant review articles were hand-searched to identify articles not captured by the electronic searches. Keywords used in the electronic searches were karate (including synonyms) in combination with injury (including truncation and synonyms). No limiters were used in the electronic searches. The complete search string for each of the databases is provided in online supplementary table 1 .

\section{Study selection}

All records from the electronic searches were combined in EndNote V.X7.8 (Thomson Reuters, Eagan, USA). Duplicate records were discarded before titles and abstracts of unique records were screened by two independent reviewers to identify and remove citations that were irrelevant or obviously did not meet the eligibility criteria. Full-text versions of all the remaining potentially eligible studies were retrieved, and these were assessed by two independent reviewers. Any disagreement was resolved by mutual consensus in consultation with a third independent reviewer.

\section{Data extraction process and data items}

Data from included studies were extracted and tabulated in an electronic spreadsheet. The data extraction was conducted independently by two independent reviewers and any inconsistencies were resolved by mutual consensus in consultation with a third independent reviewer. The data items of interest were as follows: (1) general study characteristics (eg, name of first author, year of publication, study design, study country, study setting and study period); (2) description of the study population (eg, sample size, participant demographics, level of participation); and (3) epidemiological data (eg, number of injuries and exposures, injury incidence, distribution of injuries by anatomic location, distribution of injuries by type of injury, distribution of injuries by mechanism of injury, distribution of injuries by injury severity and risk factor data). When applicable, the authors of the included studies were contacted to provide clarification or access to raw data.

\section{Risk of bias assessment}

The risk of bias in individual studies was assessed independently by two reviewers using the Newcastle-Ottawa Scale (NOS). ${ }^{11}$ The NOS for cohort studies is comprised of eight items divided into three categories: (1) selection of study groups; (2) comparability of study groups; and (3) ascertainment of outcome of interest. Because sports injury surveillance studies typically use a single exposed cohort design, the two NOS items pertaining to non-exposed study groups (ie, Selection item 2 and Comparability item 1) were disregarded in this review. Studies were awarded one star for each fulfilled item. Thus, the overall NOS scores could range from 0 to 6 stars, where more stars indicated higher study quality. The reviewers initially selected three of the included studies to pilot test the risk of bias assessment to ensure consistency before evaluating the remaining studies. Any disagreements were resolved by mutual consensus in consultation with a third independent reviewer.

Although there is no single gold standard method of assessing risk of bias across studies, examining asymmetry in the funnel plot is typically recommended. ${ }^{12}$ This review adhered to recommendations stating that examination of funnel plot asymmetry should be used only when there are at least 10 studies included in the meta-analysis and no significant heterogeneity present. $^{1213}$

\section{Data synthesis}

Study characteristics and injury and exposure data were extracted from the included studies and qualitatively synthesised and summarised. One athlete-exposure was defined as one athlete being exposed to the possibility of incurring an injury while participating in a single bout. IIR $_{\mathrm{AE}}$ and injury incidence rates per 1000 min of exposure (IIR ${ }_{\mathrm{ME}}$ ) were calculated from the available data (ie, number of injuries and exposures), whenever possible. Similarly, injury incidence rate ratios per 1000 athleteexposures $\left(\mathrm{RR}_{\mathrm{AE}}\right)$ and per $1000 \mathrm{~min}$ of exposure $\left(\mathrm{RR}_{\mathrm{ME}}\right)$ were calculated from the available data, whenever possible. All IIRs and RRs were calculated with 95\% CIs using standard methods for Poisson rates. ${ }^{14}$ In an attempt to increase the comparability across the included studies, injury proportions by anatomical region and injury type were calculated from the available data, whenever possible while adhering to the Orchard Sports Injury Classification System, V.10.1. ${ }^{15}$ 


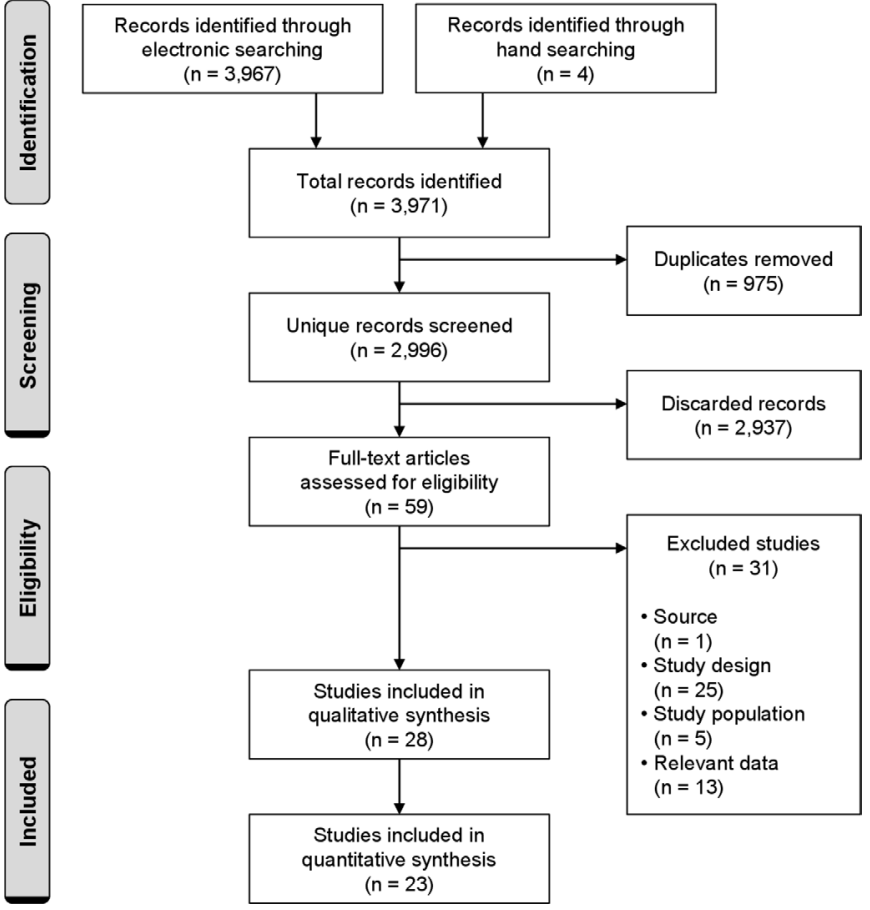

Figure 1 Flow chart of the study selection process.

Duplicated data were identified from the descriptions of study populations and settings and removed prior to quantitative synthesis. The following meta-analyses were conducted: (1) quantitative summary point estimates of $\operatorname{IIR}_{\mathrm{AE}}$ and $\operatorname{IIR}_{\mathrm{ME}}$ were obtained by fitting random-effects models with the DerSimonian and Laird procedure, including subgroup analyses by time period (ie, data from before 2000, data from 2000 to 2008 and data from 2009 onward); (2) for each risk factor of interest, quantitative summary estimates of the effect size (ie, $\mathrm{RR}_{\mathrm{ME}}$ ) were obtained by fitting random-effects models with the DerSimonian and Laird procedure. For the subgroup analyses, data from studies that included data from one or more time periods were partitioned by time period prior to analysis whenever possible. If partitioning was not possible, then the study was excluded from the subgroup analysis. Unlike fixed-effects models, random-effects models allow for between-studies variability in point estimates (ie, $\operatorname{IIR}_{\mathrm{AE}}$ and $\operatorname{IIR}_{\mathrm{ME}}$ ) and effect size estimates (ie, $\mathrm{RR}_{\mathrm{ME}}$ ) by incorporating a random-effects term for the between-studies variability into the weights. ${ }^{16} 17$ Heterogeneity was evaluated using the $\mathrm{I}^{2}$ statistic, which represents the percentage of total variation across all studies due to betweenstudy heterogeneity. ${ }^{18} 19$ All statistical analyses were conducted using the statistical software R, V.3.5.1 (R Foundation for Statistical Computing, Vienna, Austria) and the metafor package.

\section{RESULTS}

\section{Study selection}

A flow chart of the study selection process is depicted in figure 1. A total of 3971 records were identified through electronic searching of databases and hand-searching bibliographies of included studies. After removing duplicates and discarding irrelevant records, 59 potentially eligible articles remained, of which 28 articles were included. ${ }^{7-9}$ A tabular overview of potentially eligible studies that were excluded and their reasons for exclusion is provided in online supplementary table $2 .{ }^{45-75}$
Study characteristics

A descriptive overview of the included studies is provided in table 1 and tabular overview of the type of data available for extraction from each of the included studies is provided in online supplementary table 3 . Of the 28 included studies, male and female athletes were featured in 19 and 17 studies, respectively, while eight studies did not report on the sex of their study population. A total of 23 studies featured data from adult athletes, while 17 studies included data from younger athletes. While 22 studies featured data from a single country, 6 studies reported data collected in two or more countries. The majority $(n=19)$ of studies reported on data from national, regional or local karate tournaments, while nine studies featured data from international competitions (eg, World Karate Championships). Of the 28 included studies, 5 studies contained duplicate data that were reported in other included studies.

\section{Summary and synthesis of findings \\ Injury incidence}

The IIR $\mathrm{AE}_{\mathrm{AE}}$ across individual studies ranged from 29.4 (95\% CI 27.1 to 31.7 ) to 250.0 (95\% CI 201.0 to 307.3 ), while meta-analysis generated an overall summary estimate of 88.3 (95\%CI 66.6 to 117.2 ; figure 2). Subgroup analysis by time period suggested a declining IIR $_{\mathrm{AE}}$ over time, from 107.7 (95\% CI 76.8 to 151.0 ) before 2000 to 94.2 (95\% CI 72.5 to 122.4 ) during 2000-2008 to 81.3 (95\%CI 47.6 to 138.7 ) from 2009 onward (online supplementary figure 1); however, statistical comparison of the subgroup summary estimates revealed no significant differences in $\operatorname{IIR}_{\mathrm{AE}}$ across the three time periods $(Z=-1.016 ; \mathrm{p}=0.310)$.

The IIR $_{\mathrm{ME}}$ across included studies ranged from 14.7 (95\% CI 13.6 to 15.9 ) to 100.0 (95\% CI 80.4 to 122.9 ), while meta-analysis generated an overall summary estimate of 39.2 (95\% CI 30.6 to 50.2; figure 3 ). Subgroup analysis by time period suggested a declining IIR $_{\mathrm{ME}}$ over time, from 46.8 (95\% CI 34.8 to 63.1) before 2000 to 41.4 (95\% CI 32.5 to 52.6 ) during 2000-2008 to 36.6 (95\% CI 23.5 to 56.9) from 2009 onward (online supplementary figure 2); however, statistical comparison of the subgroup summary estimates revealed no significant differences in $\mathrm{IIR}_{\mathrm{ME}}$ across the three time periods $(Z=-1.014 ; \mathrm{p}=0.310)$.

\section{Injury severity}

The injury severity definitions and categorisation systems varied considerably across the 15 studies that provided data on injury severity (table 2$)$. The majority $(n=8)$ of studies used a tripartite categorisation system, although with varying terminology. Bipartite and quadripartite categorisation systems were used by three and two studies, respectively, while the remaining two studies simply reported the number of injuries requiring referral to hospital. The injury severity categorisation systems were based on either duration of time-loss from participation, the nature and type of injury, or the need for referral to hospital, or some combination of the above. Among the eight studies using a tripartite categorisation system, most injuries were in the least severe category, with the proportion ranging from $70.7 \%$ to 98.3\% (median: $83.6 \%$ ), while $0.0 \%$ to $9.8 \%$ (median: $2.8 \%$ ) of injuries were in the most severe category.

\section{Injury location and type}

A total of 19 and 14 studies provided data on the distribution of injuries by body region and type, respectively (online supplementary tables 5 and 6, respectively). The most commonly injured body regions were the head and neck (median: 57.9\%; range: $33.3 \%$ to $96.8 \%$ ) and the lower limb (median: $12.0 \%$; range: 
Table 1 Study characteristics and injury incidence rates of included studies

\begin{tabular}{|c|c|c|c|c|c|c|c|}
\hline Study & Setting & Country & Age groups & Sex & $\mathrm{IIR}_{\mathrm{AE}}(95 \% \mathrm{Cl})^{*}$ & $\mathrm{IIR}_{\mathrm{ME}}(95 \% \mathrm{CI})^{*}$ & Notes \\
\hline McLatchie $^{20}$ & Scottish Karate Championships 1975 & Scotland & Senior & NR & $135.6(107.5$ to 168.8$)$ & 67.8 (53.8 to 84.3$)$ & $\begin{array}{l}\text { Data included in } \\
\text { McLatchie and Morris }\end{array}$ \\
\hline $\begin{array}{l}\text { McLatchie and } \\
\text { Morris }^{21}\end{array}$ & $\begin{array}{l}\text { Scottish Championships 1974, 1975, } \\
\text { 1976; Scottish Budokan Championships } \\
\text { 1975, 1976: Scotland versus Germany }\end{array}$ & Scotland & Senior & NR & 53.1 (45.9 to 61.1$)$ & 26.5 (23.0 to 30.5$)$ & $\begin{array}{l}\text { Includes data from } \\
\text { McLatchie }^{20}\end{array}$ \\
\hline
\end{tabular}
match 1975

$\begin{array}{ll}\text { Stricevic et } \mathrm{al}^{22} & \text { All-American Karate Federation } \\ & \text { National Championship 1976; } \\ & \text { Regional East Coast Karate Association } \\ & \text { Tournament 1977; Canadian National } \\ & \text { Championship 1978; Pan-American } \\ & \text { Karate Championship 1978; American } \\ & \text { Continental Karate Championships } \\ & \text { 1979, } 1982\end{array}$
Nørregaard ${ }^{23}$

NR

$132.7(105.5$ to 164.7$)$

$66.3(52.8$ to 82.3$)$

Canada

Senior

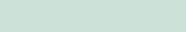

Nørregaard and
Johannsen $^{24}$

Denmark Senior

NR

115.7 (74.9 to 170.9$)$

57.9 (37.5 to 85.4$)$

Nørregaard and Johannsen ${ }^{23}$; Johannsen and Noerregaard ${ }^{25}$; and Nørregaard and Johannsen $^{25}$

\begin{tabular}{|c|c|c|c|c|c|c|c|}
\hline Johannsen ${ }^{24}$ & & & & & & & $\begin{array}{l}\text { Johannsen and } \\
\text { Nørregaard }{ }^{24} ; \\
\text { Data included in } \\
\text { Johannsen and } \\
\text { Noerregaard }{ }^{26} ; \text { and } \\
\text { Nørregaard and } \\
\text { Johannsen }^{26}\end{array}$ \\
\hline $\begin{array}{l}\text { Johannsen and } \\
\text { Noerregaard }\end{array}$ & $\begin{array}{l}\text { Danish Karate Championships 1983, } \\
\text { 1984, 1985, } 1986\end{array}$ & Denmark & Senior & NR & $124.7(109.0$ to 142.0$)$ & $62.4(54.5$ to 71.0$)$ & \\
\hline $\begin{array}{l}\text { Nørregaard and } \\
\text { Johannsen }{ }^{26}\end{array}$ & $\begin{array}{l}\text { Danish Karate Championships 1983, } \\
\text { 1984, 1985, } 1986\end{array}$ & Denmark & Senior & NR & 110.9 (90.4 to 134.6$)$ & 55.4 (45.2 to 67.3$)$ & $\begin{array}{l}\text { Data included in } \\
\text { Johannsen and } \\
\text { Noerregaard }^{26}\end{array}$ \\
\hline Trojanowski $^{27}$ & $\begin{array}{l}\text { Swedish local, regional, and national } \\
\text { tournaments } 1985 \text { to } 1986\end{array}$ & Sweden & $\begin{array}{l}\text { Senior } \\
\text { Junior }\end{array}$ & $\begin{array}{l}\text { Males } \\
\text { Females }\end{array}$ & 58.7 (48.1 to 71.1$)$ & 23.5 (19.2 to 28.4$)$ & $\begin{array}{l}\text { Number of athlete- } \\
\text { exposures estimated } \\
\text { from reported total } \\
\text { exposure time }(2243 \mathrm{~min} \\
\text { of competition } / 2 \mathrm{~min} \\
\text { per bout } \times 2 \text { athletes } \\
\text { per bout) }\end{array}$ \\
\hline $\begin{array}{l}\text { Dah and } \\
\text { Djessou }\end{array}$ & $\begin{array}{l}\text { Tournaments organised by the } \\
\text { Ivory Coast Federation of Judo and } \\
\text { Associated Disciplines, 1986, } 1987\end{array}$ & Ivory Coast & Unclear & NR & 65.5 (45.1 to 92.0$)$ & 26.2 (18.0 to 36.8$)$ & \\
\hline Hillman et al ${ }^{29}$ & Australian national tournament 1990 & Australia & Senior & $\begin{array}{l}\text { Males } \\
\text { Females }\end{array}$ & 250.0 (201.0 to 307.3$)$ & 100.0 (80.4 to 122.9$)$ & \\
\hline Tuominen $^{30}$ & $\begin{array}{l}\text { Finnish national tournaments, 1991, } \\
1992\end{array}$ & Finland & $\begin{array}{l}\text { Senior } \\
\text { Junior }\end{array}$ & $\begin{array}{l}\text { Males } \\
\text { Females }\end{array}$ & $138.9(115.6$ to 165.5$)$ & 55.6 (46.2 to 66.2$)$ & \\
\hline Esenkaya $^{7}$ & $\begin{array}{l}\text { World Karate Championships, 1990, } \\
1992\end{array}$ & $\begin{array}{l}\text { Mexico } \\
\text { Spain }\end{array}$ & Senior & $\begin{array}{l}\text { Males } \\
\text { Females }\end{array}$ & 221.0 (204.1 to 238.8$)$ & 88.4 (81.7 to 95.5$)$ & \\
\hline Critchley et $\left.a\right|^{31}$ & $\begin{array}{l}\text { British Shotokan Karate Championships } \\
\text { 1996, 1997, } 1998\end{array}$ & UK & All age groups & $\begin{array}{l}\text { Males } \\
\text { Females }\end{array}$ & 45.2 (38.5 to 52.8$)$ & 22.6 (19.2 to 26.4$)$ & \\
\hline Macan et $a \beta^{32}$ & $\begin{array}{l}\text { Croatian regional and national } \\
\text { tournaments } 1997\end{array}$ & Croatia & All age groups & $\begin{array}{l}\text { Males } \\
\text { Females }\end{array}$ & 117.0 (101.6 to 134.2$)$ & 50.7 (44.0 to 58.1$)$ & $\begin{array}{l}\text { Data included in Macan } \\
\text { et } a l^{32}\end{array}$ \\
\hline $\begin{array}{l}\text { Arriaza and } \\
\text { Leyes }^{33}\end{array}$ & $\begin{array}{l}\text { World Karate Championships 1996, } \\
\text { 1998, } 2000\end{array}$ & $\begin{array}{l}\text { South Africa } \\
\text { Brazil } \\
\text { Germany }\end{array}$ & Senior & $\begin{array}{l}\text { Males } \\
\text { Females }\end{array}$ & $157.0(146.9$ to 167.7$)$ & $58.0(54.2$ to 61.9$)$ & \\
\hline Macan et $\left.a\right|^{34}$ & $\begin{array}{l}\text { Croatian regional and national } \\
\text { tournaments, 1997, } 2002\end{array}$ & Croatia & All age groups & $\begin{array}{l}\text { Males } \\
\text { Females }\end{array}$ & 92.7 (84.4 to 101.6$)$ & 50.1 (45.7 to 54.9$)$ & \\
\hline Halabchi et $a l^{35}$ & $\begin{array}{l}\text { Iranian Woman's National Shotokan } \\
\text { Karate Championships, 2004, } 2005\end{array}$ & Iran & All age groups & Females & 81.7 (70.3 to 94.3$)$ & 40.8 (35.2 to 47.1$)$ & \\
\hline Arriaza et $a l^{36}$ & $\begin{array}{l}\text { World Karate Championships 2002, } \\
\text { 2004, } 2006\end{array}$ & $\begin{array}{l}\text { Spain } \\
\text { Mexico } \\
\text { Finland }\end{array}$ & Senior & $\begin{array}{l}\text { Males } \\
\text { Females }\end{array}$ & 90.0 (82.2 to 98.2$)$ & 33.5 (30.6 to 36.5$)$ & \\
\hline Aono et $a l^{8}$ & World Karate Championships 2008 & Japan & Senior & $\begin{array}{l}\text { Males } \\
\text { Females }\end{array}$ & 81.4 (70.4 to 93.5$)$ & 31.0 (26.9 to 35.7$)$ & \\
\hline Minami ${ }^{9}$ & $\begin{array}{l}\text { Japanese regional tournaments } \\
\text { 1997-2008 }\end{array}$ & Japan & All age groups & $\begin{array}{l}\text { Males } \\
\text { Females }\end{array}$ & 29.4 (27.1 to 31.7$)$ & 14.7 (13.6 to 15.9$)$ & \\
\hline Rahimi et al ${ }^{37}$ & Iranian international tournament 2009 & Iran & Senior & Males & 192.1 (150.6 to 241.5$)$ & $64.0(50.2$ to 80.5$)$ & \\
\hline
\end{tabular}




\begin{tabular}{|c|c|c|c|c|c|c|c|}
\hline Study & Setting & Country & Age groups & Sex & $\mathrm{IIR}_{\mathrm{AE}}(95 \% \mathrm{CI})^{*}$ & $\mathrm{IIR}_{\mathrm{ME}}(95 \% \mathrm{Cl})^{*}$ & Notes \\
\hline Pieter $^{38}$ & $\begin{array}{l}\text { Dutch Youth Karate Championship } \\
2009\end{array}$ & $\begin{array}{l}\text { The } \\
\text { Netherlands }\end{array}$ & $\begin{array}{l}\text { Cadet (14-15 } \\
\text { years) } \\
\text { Child (7-13 } \\
\text { years) }\end{array}$ & $\begin{array}{l}\text { Males } \\
\text { Females }\end{array}$ & $103.8(85.2$ to 125.4$)$ & 69.2 (56.8 to 83.6) & \\
\hline Rosso et a $\left.\right|^{39}$ & European Karate Championships 2011 & Germany & Senior & $\begin{array}{l}\text { Males } \\
\text { Females }\end{array}$ & 51.7 (36.9 to 70.4$)$ & 20.3 (14.5 to 27.6$)$ & \\
\hline Boostani et a $/^{40}$ & $\begin{array}{l}\text { Iranian national team selection } \\
\text { tournament } 2011\end{array}$ & Iran & Senior & Males & 168.7 (138.9 to 203.0$)$ & 56.2 (46.3 to 67.7$)$ & \\
\hline Boostani et al ${ }^{41}$ & $\begin{array}{l}\text { Iranian national team selection } \\
\text { tournament } 2012\end{array}$ & Iran & Senior & Males & 192.6 (165.4 to 223.1) & $64.2(55.1$ to 74.4$)$ & \\
\hline Arriaza et $a l^{42}$ & $\begin{array}{l}\text { World Karate Championships 2009, } \\
\text { 2011, } 2013\end{array}$ & $\begin{array}{l}\text { Morocco } \\
\text { Malaysia } \\
\text { Spain }\end{array}$ & $\begin{array}{l}\text { Cadet }(14-15 \\
\text { years) }\end{array}$ & $\begin{array}{l}\text { Males } \\
\text { Females }\end{array}$ & 29.9 (22.9 to 38.4$)$ & 15.0 (11.4 to 19.2$)$ & \\
\hline $\begin{array}{l}\text { Čierna and } \\
\text { Lystad }^{43}\end{array}$ & $\begin{array}{l}\text { Slovak national youth tournaments } \\
2015 \text { to } 2016\end{array}$ & Slovakia & $\begin{array}{l}\text { Junior (16-17 } \\
\text { years) } \\
\text { Cadet (12-15 } \\
\text { years) } \\
\text { Child (6-11 } \\
\text { years) }\end{array}$ & $\begin{array}{l}\text { Males } \\
\text { Females }\end{array}$ & 45.3 (38.7 to 52.6$)$ & 35.9 (30.7 to 41.7$)$ & \\
\hline Čierna et $a l^{44}$ & $\begin{array}{l}\text { World Karate Championships 2009, } \\
\text { 2011, 2013, } 2015\end{array}$ & $\begin{array}{l}\text { Morocco } \\
\text { Malaysia } \\
\text { Spain } \\
\text { Indonesia }\end{array}$ & $\begin{array}{l}\text { Under } 21 \text { (18-20 } \\
\text { years) } \\
\text { Junior (16-17 } \\
\text { years) }\end{array}$ & $\begin{array}{l}\text { Males } \\
\text { Females }\end{array}$ & $41.4(36.5$ to 46.7$)$ & 17.8 (15.7 to 20.2$)$ & \\
\hline
\end{tabular}

${ }^{*}$ Calculated from the available injury and exposure data if not reported.

$\| \mathrm{R}_{\mathrm{AE}^{\prime}}$ injury incidence rates per 1000 athlete-exposures; $\mathrm{IR}_{\mathrm{ME}^{\prime}}$ injury incidence rates per 1000 min of exposure; NR, not reported.

$2.4 \%$ to $26.1 \%)$. The most frequent types of injury were contusion (median: 68.3\%; range: $54.9 \%$ to $95.1 \%$ ) and laceration (median: $18.6 \%$; range: $0.0 \%$ to $29.3 \%$ ). Concussion accounted for $0.0 \%$ to $7.5 \%$ (median: $2.0 \%$ ) of reported injuries.

\section{Mechanism of injury}

A total of 14 studies reported on the mechanism of injury (online supplementary table 7). The most common mechanism of injury was punching, accounting for $48.4 \%$ to $87.0 \%$ (median: $67.0 \%$ ) of reported injuries. Kicking, blocking and falling accounted for $7.3 \%$ to $35.7 \%$ (median: $20.7 \%$ ), $2.8 \%$ to $18.3 \%$ (median: $10.0 \%$ ) and $0.9 \%$ to $17.3 \%$ (median: $3.7 \%$ ) of reported injuries, respectively.
Risk factors for injury

An overview of data on risk factors from the included studies is provided in table 3 . Thirteen studies reported data that allowed comparison by sex. The $\mathrm{RR}_{\mathrm{AE}}$ and $\mathrm{RR}_{\mathrm{ME}}$ for males versus females varied from 0.78 to 2.48 and from 0.73 to 1.98 , respectively. Meta-analysis revealed a significantly higher injury rate per exposure for males compared with females $\left(\mathrm{RR}_{\mathrm{AE}} 1.27,95 \% \mathrm{CI}\right.$ 1.03 to 1.55 , online supplementary figure 3 ); however, there was no significant difference in injury rates accounting for exposuretime between males and females $\left(\mathrm{RR}_{\mathrm{ME}} 1.09\right.$, 95\% CI 0.88 to 1.36, online supplementary figure 4).

In regard to age, the injury rate per exposure was generally higher for senior athletes than junior athletes $\left(\mathrm{RR}_{\mathrm{AE}}\right.$ range: 1.03

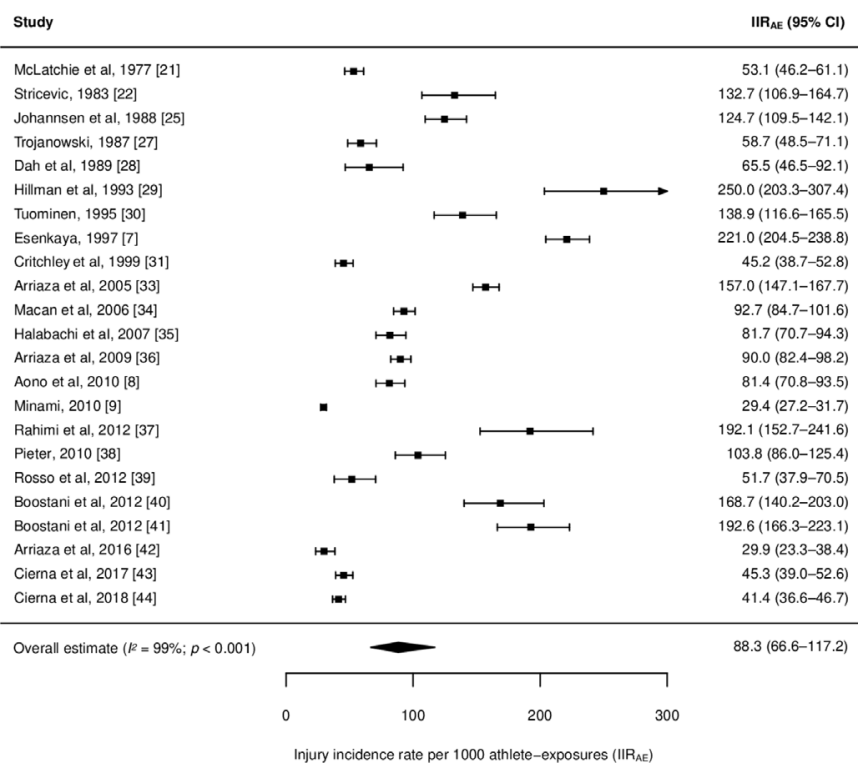

Figure 2 Forest plot of meta-analysis of injury incidence rates per 1000 athlete-exposures (IIR $\left.{ }_{\mathrm{AE}}\right)$.

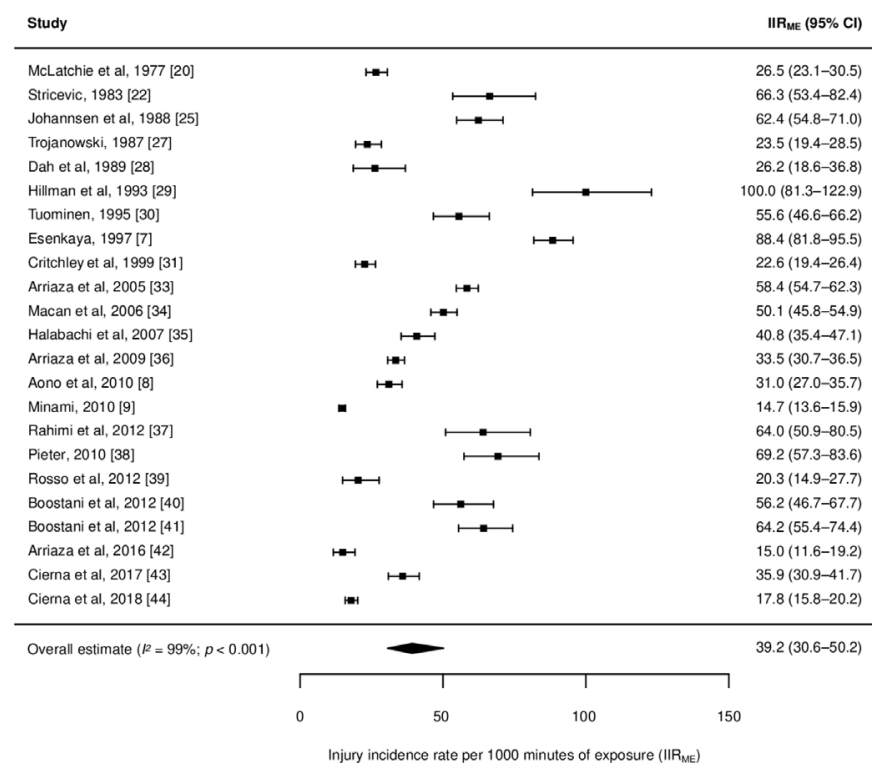

Figure 3 Forest plot of meta-analysis of injury incidence rates per 1000 min of exposure $\left(\mathrm{IIR}_{\mathrm{ME}}\right)$. 


\begin{tabular}{|c|c|c|c|}
\hline Study & $\mathrm{N}$ & Severity & Severity definition \\
\hline McLatchie $^{20}$ & 80 & $\begin{array}{l}65.0 \% \text { no time-loss } \\
35.0 \% \text { time-loss }\end{array}$ & Not reported \\
\hline Stricevic et a $a^{22}$ & $76^{*}$ & $\begin{array}{l}78.9 \% \text { Grade } 1 \\
19.7 \% \text { Grade } 2 \\
1.3 \% \text { Grade } 3\end{array}$ & $\begin{array}{l}\text { Grade 1: athlete able to continue competition } \\
\text { Grade 2: athlete forced to withdraw from competition } \\
\text { Grade 3: athlete referred to hospital }\end{array}$ \\
\hline Trojanowski $^{27}$ & 105 & $\begin{array}{l}95.2 \% \text { mild } \\
4.8 \% \text { moderate } \\
0.0 \% \text { severe }\end{array}$ & $\begin{array}{l}\text { Mild: }<1 \text { week time-loss } \\
\text { Moderate: }>1 \text { week, but }<1 \text { month time-loss } \\
\text { Severe: }>1 \text { month time-loss }\end{array}$ \\
\hline Dah and Djessou ${ }^{28}$ & 33 & $3.0 \%$ referred to hospital & Not reported \\
\hline Arriaza and Leyes ${ }^{33}$ & 891 & $\begin{array}{l}89.3 \% \text { minor } \\
7.9 \% \text { moderate } \\
2.8 \% \text { severe }\end{array}$ & $\begin{array}{l}\text { Categorised as minor/mild, moderate or severe/major based on type of injury as per WKF injury severity classification } \\
\text { (see online supplementary table 4) }\end{array}$ \\
\hline Macan et $a l^{34}$ & 462 & $\begin{array}{l}98.3 \% \text { Grade } 1 \\
1.5 \% \text { Grade } 2 \\
0.2 \% \text { Grade } 3\end{array}$ & $\begin{array}{l}\text { Grade 1: athlete able to continue competition } \\
\text { Grade 2: athlete forced to withdraw from competition } \\
\text { Grade 3: athlete referred to hospital }\end{array}$ \\
\hline Halabachi et al ${ }^{35}$ & 186 & $\begin{array}{l}80.1 \% \text { Grade } 1 \\
14.5 \% \text { Grade } 2 \\
5.4 \% \text { Grade } 3\end{array}$ & $\begin{array}{l}\text { Grade 1: athlete able to continue competition } \\
\text { Grade 2: athlete forced to withdraw from competition } \\
\text { Grade 3: athlete referred to hospital }\end{array}$ \\
\hline Arriaza et a $\beta^{36}$ & 497 & $\begin{array}{l}87.1 \% \text { minor } \\
8.0 \% \text { moderate } \\
4.8 \% \text { severe }\end{array}$ & $\begin{array}{l}\text { Categorised as minor/mild, moderate, or severe/major based on type of injury as per WKF injury severity classification } \\
\text { (see online supplementary table 4) }\end{array}$ \\
\hline Minami ${ }^{9}$ & 633 & $4.6 \%$ referred to hospital & Not reported \\
\hline Rahimi et $a^{37}$ & $75+$ & $\begin{array}{l}80.0 \% \text { mild } \\
17.3 \% \text { moderate } \\
2.7 \% \text { severe }\end{array}$ & $\begin{array}{l}\text { Categorised as minor/mild, moderate, or severe/major based on type of injury as per WKF injury severity classification } \\
\text { (see online supplementary table 4) }\end{array}$ \\
\hline Rosso et al ${ }^{39}$ & 40 & $\begin{array}{l}70.7 \% \text { minor } \\
19.5 \% \text { moderate } \\
9.8 \% \text { severe }\end{array}$ & Not reported \\
\hline Boostani et a $l^{40}$ & 112 & $\begin{array}{l}95.5 \% \text { light } \\
2.7 \% \text { mild } \\
0.9 \% \text { moderate } \\
0.9 \% \text { high }\end{array}$ & Not reported \\
\hline Boostani et al ${ }^{41}$ & 178 & $\begin{array}{l}83.7 \% \text { light } \\
10.1 \% \text { mild } \\
3.9 \% \text { moderate } \\
2.2 \% \text { severe }\end{array}$ & Not reported \\
\hline Arriaza et $a^{42}$ & 61 & $\begin{array}{l}95.1 \% \text { minor } \\
4.9 \% \text { time-loss }\end{array}$ & $\begin{array}{l}\text { Minor: athlete able to continue competition } \\
\text { Time-loss: athlete forced to withdraw from competition }\end{array}$ \\
\hline Čierna et $a^{14}$ & 257 & $\begin{array}{l}89.9 \% \text { minor } \\
10.1 \% \text { time-loss }\end{array}$ & $\begin{array}{l}\text { Minor: athlete able to continue competition } \\
\text { Time-loss: athlete forced to withdraw from competition }\end{array}$ \\
\hline
\end{tabular}

*Number of injured athletes.

tIncludes $n=2$ kata-related injuries.

WKF, World Karate Federation.

to 1.75$)$; however, when comparing injury rates accounting for exposure-time the risk was generally lower for senior athletes than junior athletes $\left(\mathrm{RR}_{\mathrm{ME}}\right.$ range: 0.69 to 0.88$)$.

Two studies reported data allowing comparison of injury rates by competition format (ie, team vs individual). Their findings were inconsistent. Whereas one study found a significantly higher injury rate in team competition $\left(\mathrm{RR}_{\mathrm{ME}} 1.67,95 \% \mathrm{CI} 1.12\right.$ to 2.48$)$, the other reported a lower injury rate $\left(\mathrm{RR}_{\mathrm{ME}} 0.89,95 \%\right.$ CI 0.75 to 1.07$)$.

Five studies reported data allowing comparison of injury risk before and after changes to competition rules. Four studies found no significant differences in injury risk before and after rule changes in the mid-1980s, ${ }^{25}$ early $1990 \mathrm{~s}^{7}$ and in $2000 .^{33} 34$ However, the most recent study found a significantly lower injury risk after the introduction of new competition rules in 2015 $\left(\mathrm{RR}_{\mathrm{ME}} 0.43,95 \% \mathrm{CI} 0.30\right.$ to 0.59$\left.]\right)$.

\section{Risk of bias assessment}

A complete overview of the risk of bias assessment using the NOS is provided in online supplementary table 8 . Out of a possible total of six stars, 24 studies received five stars, three studies received four stars and one study received three stars.

\section{DISCUSSION}

This is the first systematic review and meta-analysis on the epidemiology of injuries in Olympic-style karate competitions. It highlights the sport's relatively high injury incidence rate and distinct distribution of injuries by location and type. Our review provides an overview of the strengths and weaknesses of the body of literature and offers recommendations for future research.

\section{Injury incidence}

The overall $\operatorname{IIR}_{\mathrm{AE}}$ and $\mathrm{IIR}_{\mathrm{ME}}$ in Olympic-style karate athletes were 88.3 and 39.2 , respectively. Our injury rate estimates were substantially lower than the weighted averages reported by Thomas and Ornstein, ${ }^{6}$ who reported IIR $_{\mathrm{AE}}$ of 111.4 for males and 105.8 for females and $\mathrm{IIR}_{\mathrm{ME}}$ of 75.4 for males and 72.8 for females. There are several reasons for these differences: (1) we included studies of Olympic-style karate published in peerreviewed journal articles only, whereas Thomas and Ornstein ${ }^{6}$ included studies investigating other forms of karate 565960 and data from non-peer-reviewed sources ${ }^{76-78}$; (2) we included three non-English articles ${ }^{7-9}$ that were omitted by Thomas and Ornstein $^{6}$; and (3) we disaggregated the findings from two 
Table 3 Injury incidence rate ratios per 1000 athlete-exposures $\left(R_{\mathrm{AE}}\right)$ and per 1000 min of exposure $\left(\mathrm{RR}_{\mathrm{ME}}\right)$

\begin{tabular}{|c|c|c|c|c|}
\hline Factor & Comparison & $\mathrm{RR}_{\mathrm{AE}}(95 \% \mathrm{Cl})$ & $\mathrm{RR}_{\mathrm{ME}}(95 \% \mathrm{Cl})$ & Study \\
\hline \multicolumn{5}{|l|}{ Sex } \\
\hline & Male (ref. female) & NR & 1.03 (0.58 to 1.84 ) & Trojanowski $^{27}$ \\
\hline & Male (ref. female) & 1.98 (1.04 to 3.77$)$ & 1.98 (1.04 to 3.77$)$ & Tuominen $^{30}$ \\
\hline & Male (ref. female) & 1.14 (0.84 to 1.53$)$ & 1.21 (0.89 to 1.63 ) & Macan et $a^{\beta 2}$ \\
\hline & Male (ref. female) & $1.10(0.95$ to 1.27$)$ & 0.73 (0.63 to 0.85$)$ & Arriaza and Leyes ${ }^{33}$ \\
\hline & Male (ref. female) & 0.81 (0.62 to 1.04$)$ & 0.74 (0.57 to 0.95$)$ & Macan et $a^{\beta^{4}}$ \\
\hline & Male (ref. female) & 1.91 (1.57 to 2.33$)$ & 1.91 (1.57 to 2.33 ) & Minami $^{9}$ \\
\hline & Male (ref. female) & 0.87 (0.57 to 1.31$)$ & 0.87 (0.57 to 1.31$)$ & Pieter $^{38}$ \\
\hline & Male (ref. female) & 2.48 (1.21 to 5.07$)$ & 1.65 (0.81 to 3.38$)$ & Rosso et al ${ }^{39}$ \\
\hline & Male (ref. female) & 0.80 (0.48 to 1.34$)$ & 0.80 (0.48 to 1.34$)$ & Arriaza et $a l^{42}$ \\
\hline & Male (ref. female) & $0.78(0.58$ to 1.06$)$ & 0.80 (0.59 to 1.09$)$ & Čierna and Lystad ${ }^{43}$ \\
\hline & Senior (ref. junior/cadet (15-21 years)) & 1.03 (0.76 to 1.41$)$ & 0.69 (0.50 to 0.94 ) & Macan et a $\left.\right|^{32}$ \\
\hline & Senior (ref. pupil/young cadet (10-14 years)) & 1.75 (1.15 to 2.67$)$ & 0.58 (0.38 to 0.89$)$ & Macan et $a \beta^{32}$ \\
\hline & Junior/cadet (15-21 years, ref. pupil/young cadet (10-14 years)) & 1.68 (1.06 to 2.65$)$ & 0.84 (0.54 to 1.34$)$ & Macan et $a^{32}$ \\
\hline & $\geq 18$ years (ref. $<18$ years) & 1.75 (1.35 to 2.27$)$ & 0.88 (0.68 to 1.14$)$ & Macan et $a^{\beta 4}$ \\
\hline & Junior/cadet (12-17 years, ref. child (6-11 years)) & 2.85 (2.07 to 3.93$)$ & 1.92 (1.39 to 2.65$)$ & Čierna and Lystad ${ }^{43}$ \\
\hline & Under 21 (18-20 years, ref. junior (16-17 years)) & 1.31 (1.02 to 1.67$)$ & $0.96(0.75$ to 1.23$)$ & Čierna et $a l^{44}$ \\
\hline \multicolumn{5}{|c|}{ Competition format } \\
\hline & Team (ref. individual) & NR & 1.67 (1.12 to 2.48$)$ & Trojanowski $^{27}$ \\
\hline & Shobo sanbon (ref. Shobo ipon) & 1.27 (0.96 to 1.68$)$ & NR & Esenkaya $^{7}$ \\
\hline & Team (ref. individual) & $0.88(0.74$ to 1.05$)$ & 0.89 (0.75 to 1.07$)$ & Arriaza and Leyes ${ }^{36}$ \\
\hline
\end{tabular}

NR, not reported; WKC, world karate championship.

studies $^{39} 42$ that Thomas and Ornstein ${ }^{6}$ incorrectly assumed provided duplicated data.

Compared with the injury risk in other popular Olympic combat sports, the $\operatorname{IIR}_{\mathrm{AE}}$ in karate is similar to that reported for taekwondo (pooled estimate: 79.3) ${ }^{79}$ but higher than that reported for judo (range: 41.2 to 81.6 ) and wrestling (weighted average: 16.3). ${ }^{80}{ }^{81}$ Although the $\operatorname{IIR}_{\mathrm{AE}}$ in these Olympic combat sports is relatively high compared with other sports, the injury risk is nevertheless substantially lower than that observed for other non-Olympic full-contact combat sports such as mixed martial arts (pooled estimate: 228.7 ) and kickboxing (390.1). ${ }^{8283}$

\section{Injury location and type}

We found that the head and neck was the most commonly injured body region in karate (median: $57.9 \%$ ), with contusions and lacerations being the most frequent injury types (median: $68.3 \%$ and $18.6 \%$, respectively). This distribution of injuries by body location is not surprising given that the head is the most frequently attacked scoring target in karate. ${ }^{84}$ Because there are both similarities and unique features across individual combat sports in terms of competition rules (eg, permissible techniques and targets), it is unsurprising to find both similarities and differences in the distribution of injuries across combat sports. For instance, the proportion of injuries to the head and neck region in karate is lower than in boxing, similar to that in mixed martial arts and kickboxing, but higher than in taekwondo and judo. Those sports, on the other hand, have higher proportions of lower limb and upper limb injuries, respectively. ${ }^{85}$ This is perhaps not surprising given that taekwondo athletes wear protective headgear, while striking the head is not permitted in judo. Although contusions and lacerations are relatively common in most full-contact combat sports, the proportion of lacerations is higher in boxing and mixed martial arts compared with karate. ${ }^{85}$

Our review underscores the importance of using exposure-time adjusted injury rates when comparing injury risk across subgroups. For instance, although males had a significantly higher $\operatorname{IIR}_{\mathrm{AE}}$ compared with females $\left(\mathrm{RR}_{\mathrm{AE}} 1.27,95 \% \mathrm{CI} 1.03\right.$ to 1.55$)$, there was no significant difference in IIR between males and females $\left(\mathrm{RR}_{\mathrm{ME}} 1.09,95 \%\right.$ CI 0.88 to 1.36$)$. Similarly, senior athletes had higher IIR $\mathrm{AF}_{\mathrm{AE}}$, but lower IIR $\mathrm{ME}_{\mathrm{ME}}$, compared with junior athletes $\left(\mathrm{RR}_{\mathrm{AE}}\right.$ range: 1.03 to 1.75 ; $\mathrm{RR}_{\mathrm{ME}}$ range: 0.69 to 0.88 ). These apparent inconsistencies are explained by the fact that the duration of bouts varies by sex and age group. That is, 3 min for senior males, $2 \mathrm{~min}$ 
for senior females, $3 \mathrm{~min}$ for under 21 year olds, 2 min for juniors and cadets and $1.5 \mathrm{~min}$ or $1 \mathrm{~min}$ for younger children.

\section{Strengths}

Our review has several strengths. First, we employed a comprehensive search strategy, which included electronic searching of five databases using relatively broad search terms without any restrictions on publication date or language. Electronic database searching was supplemented by hand-searching the bibliographies of all included studies. The comprehensiveness of our literature search is evidenced by the fact we identified and included three articles that were missed by two previous reviews. ${ }^{5}$ Second, our review was designed to be more applicable to Olympic-style karate, which is the most popular and widely practiced form of karate worldwide. Third, in an attempt to improve the quality of our summary estimates, we carefully omitted duplicate data in our meta-analyses. Fourth, unlike previous reviews of karate injuries, ${ }^{56}$ we assessed the risk of bias of included studies using a standardised tool.

\section{Limitations}

There was strong evidence of heterogeneity, suggesting high variation in injury incidence rates across the included studies. The high variability in injury incidence rates may be related to methodological variations (eg, injury surveillance methods and operational injury definitions), variability in study populations (eg, level of competition, geographical location, age groups and sex) and variability in competition rules (eg, rule changes over time). Because high heterogeneity is a relatively common issue in metaanalysis of injury incidence rates, we used a random-effects model which allows for between-studies variability by incorporating a random-effects term for the between-studies variability into the weights. ${ }^{1617}$ However, it is important to note that compared with fixed-effects models, random-effects models will assign relatively greater weights to smaller datasets, ${ }^{86}$ which may have resulted in overestimating the injury incidence rates in our meta-analysis. The presence of high heterogeneity made it difficult to assess possible publication bias in our review. The methods to test for publication bias in the presence of heterogeneity generally have insufficient statistical power unless the meta-analysis is very large. ${ }^{87}$

\section{Recommendations for future research}

We make several recommendations to improve research on injuries in karate:

1. Most importantly, future studies should adhere to definitions and data collection procedures outlined in the recent IOC consensus statement on methods for recording and reporting epidemiological data from injury and illness surveillance in sports. ${ }^{88}$ This includes, but is not necessarily limited to, clearly articulating operational injury and exposure definitions; classifying mode and mechanism of injury using consensus categories; and adhering to a standardised sports-specific coding system for classifying injuries by anatomical location and type of pathology.

2. In regard to the classification of injuries by anatomical location and type of pathology, future research should take note of the revisions of the two most commonly used coding systems for classifying sports injuries that accompanies the recent IOC consensus statement. ${ }^{89}$ This will facilitate crossstudy comparisons and reduce unnecessary heterogeneity.

3. We encourage researchers to use specific exposure units that account for the time-at-risk (eg, minutes of exposure). This will allow for more appropriate and meaningful com-
What is already known?

Karate will debut at the Tokyo 2020 Olympic Games (postponed to 23 July to 8 August 2021)

\section{What are the new findings?}

- Karate athletes sustain, on average, 1 injury every 11 exposures or every 25 min of competition.

- Most injuries are reported in the least severe category.

- There is no difference in injury incidence rates accounting for exposure-time between male and female athletes.

- Injury incidence rates accounting for exposure-time are generally higher for adult athletes than for younger athletes.

parisons of injury risk between subgroups with varying bout durations. Ideally, future studies should record actual bout duration for all exposures.

4. We also recommend that future studies determine the severity of injuries using objective measurements of actual time lost to participation in training or competition. As per the recent IOC consensus statement, we recommend the following time bins: 0 days, $1-7$ days, $8-28$ days and $>28$ days. ${ }^{88}$

5. Future studies should investigate a broader range of potential risk factors for injury in karate and report data for as many subgroups (eg, by sex, age group, weight division and individual vs team competition) as possible to allow for subgroup comparisons in future meta-analyses.

\section{Twitter Reidar P Lystad @RLystad}

Acknowledgements We would like to thank Chrissy Imai for Onur Ates for their assistance with translating Japanese and Turkish language articles, respectively. We would also like to thank all the corresponding authors of the included studies who responded to our requests for clarifications and additional information.

Contributors RPL, GH, KB, DC and RA designed the study and approved the final manuscript. RPL conducted the analysis and wrote the first draft of the manuscript. RPL, DC and RA interpreted the findings and reviewed and edited the manuscript. All authors approved the final manuscript.

Funding The authors have not declared a specific grant for this research from any funding agency in the public, commercial or not-for-profit sectors.

Competing interests DC is a member of the Technical Commission of the European Karate Union and RA is the Chair of Medical Commission of the World Karate Federation; however, neither DC nor RA receive any remuneration from the European Karate Union or the World Karate Federation to conduct this study, and neither the European Karate Union nor the World Karate Federation have had any influence on this work.

\section{Patient consent for publication Not required.}

Ethics approval This systematic review and meta-analysis was exempt from seeking approval from the local institutional review board because it retrieves and synthesises data from publicly accessible documents (ie, published research articles) that do not contain any personal identifying information.

Provenance and peer review Not commissioned; externally peer reviewed.

\section{ORCID iD}

Reidar P Lystad http://orcid.org/0000-0003-0506-0902

\section{REFERENCES}

1 The Tokyo Organising Committee of the Olympic and Paralympic Games. Karate, 2019 Available: https://tokyo2020.org/en/games/sport/olympic/karate/ [Accessed 29 Mar 2019].

2 World Karate Federation. Structure - members, 2019. Available: https://www.wkf.net/ structure-country-members.php [Accessed 10 Dec 2019].

3 Committee IO. Joint statement from the International Olympic Committee and the Tokyo 2020 organising Committee, 2020. Available: https://www.olympic.org/news/ 
joint-statement-from-the-international-olympic-committee-and-the-tokyo-2020organising-committee [Accessed 9 Jul 2020].

4 World Karate Federation. Sport - Understanding Karate - Rules \& Regulations, 2019 Available: https://www.wkf.net/ksport-rules-regulations.php [Accessed 29 Mar 2019].

5 Sterkowicz S, Sterkowicz-Przybycień K. Injuries in karate: a review. OA Sports Medicine 2013;1:14.

6 Thomas RE, Ornstein J. Injuries in karate: systematic review. Phys Sportsmed 2018:46:279-303.

7 Esenkaya I. Injuries and health care in sports halls in international karate competition. Turkish J Sports Med 1997;32:193-204.

8 Aono H, Suzuki H, Katayama K, et al. External injuries in karatedo at the 19th World Karate Championship in Tokyo [Japanese]. Journal of Sports Dentistry 2010;14:29-34

9 Minami M. Sports injuries in karate competitions [Japanese]. Japanese Journal of Clinical Sports Medicine 2010;18:343-8.

10 Moher D, Liberati A, Tetzlaff J, et al. Preferred reporting items for systematic reviews and meta-analyses: the PRISMA statement. Ann Intern Med 2009;151:264-9.

11 Wells G, Shea B, O'Connell D, et al. The Newcastle-Ottawa scale (NOS) for assessing the quality of nonrandomised studies in meta-analysis, 2011. Available: http://www.ohri.ca/programs/clinical_epidemiology/oxford.asp [Accessed 1 April 2019].

12 Lau J, loannidis JPA, Terrin N, et al. The case of the misleading funnel plot. BMJ 2006:333:597-600

13 Sterne JA, Egger M. Funnel plots for detecting bias in meta-analysis: guidelines on choice of axis. J Clin Epidemiol 2001;54:1046-55.

14 Rothman KJ, Greenland S, Lash TL, eds. Modern epidemiology. 3rd ed. Philadelphia, PA: Lippincott Williams \& Wilkins, 2008.

15 Rae K, Orchard J. The orchard sports injury classification system (OSICS) version 10. Clin J Sport Med 2007:17:201-4.

16 Borenstein M, Hedges LV, Higgins JPT, et al. A basic introduction to fixed-effect and random-effects models for meta-analysis. Res Synth Methods 2010;1:97-111.

17 Riley RD, Higgins JPT, Deeks JJ. Interpretation of random effects meta-analyses. BMJ 2011;342:d549.

18 Higgins JPT, Thompson SG. Quantifying heterogeneity in a meta-analysis. Stat Med 2002;21:1539-58

19 Higgins JPT, Thompson SG, Deeks JJ, et al. Measuring inconsistency in meta-analyses. BMJ 2003;327:557-60.

20 McLatchie GR. Analysis of karate injuries sustained in 295 contests. Injury 1976:8:132-4.

21 McLatchie GR, Morris EW. Prevention of karate injuries--a progress report. Br J Sports Med 1977:11:78-82.

22 Stricevic MV, Patel MR, Okazaki T, et al. Karate: historical perspective and injuries sustained in national and international tournament competitions. Am J Sports Med 1983;11:320-4.

23 Johannsen HV, Nørregaard FO. [Karate injuries in relation to the qualifications of participants and competition success]. Ugeskr Laeger 1986;148:1786-90.

24 Nørregaard FO, Johannsen HV. [Pattern of injuries in Danish karate championships]. Ugeskr Laeger 1986;148:1785-6.

25 Johannsen HV, Noerregaard FO. Prevention of injury in karate. Br J Sports Med 1988;22:113-5.

26 Nørregaard FO, Johannsen HV. [The preventive effect of protective fist pads in the individual Danish karate championships]. Ugeskr Laeger 1988;150:354-6.

27 Trojanowski D. [Injuries during karate competitions--identification of risk groups]. Lakartidningen 1987;84:1858-60.

28 Dah C, Djessou P. Accidents et incidents lies Au judo et Au karate Au cours D' une saison sportive (1986-1987) en Cote D' Ivoire. Cinesiologie 1989:28:153-7.

29 Hillman S, Dicker G, Sali A. Non contact karate injuries. Aust J Sci Med Sport 1993:25:73-5.

30 Tuominen R. Injuries in national karate competitions in Finland. Scand J Med Sci Sports 1995:5:44-8.

31 Critchley GR, Mannion S, Meredith C. Injury rates in Shotokan karate. Br J Sports Med 1999;33:174-7

32 Macan J, Bundalo D, Romic G. The prevalence and distribution of injuries in karate (kumite). Kinesiology 2001;33:137-45.

33 Arriaza R, Leyes M. Injury profile in competitive karate: prospective analysis of three consecutive world karate Championships. Knee Surg Sports Traumatol Arthrosc 2005;13:603-7.

34 Macan J, Bundalo-Vrbanac D, Romić G. Effects of the new karate rules on the incidence and distribution of injuries. Br J Sports Med 2006:40:326-30.

35 Halabchi F, Ziaee V, Lotfian S. Injury profile in women shotokan karate championships in Iran (2004-2005). J Sports Sci Med 2007;6:52-7.

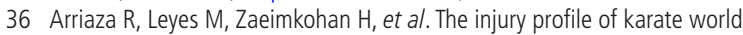
Championships: new rules, less injuries. Knee Surg Sports Traumatol Arthrosc 2009:17:1437-42

37 Rahimi M, Halabchi F, Alibakhshi E, et al. Sport injuries of karatekas at international competitions. Iranian Journal of Military Medicine 2012:13:1-6.

38 Pieter W. Competition injury rates in young karate athletes. Sci Sports 2010;25:32-8.
39 Rosso C, Zenhäusern R, Mark Müller A, et al. Karate-do - the path of the empty hand Sport-Orthopädie - Sport-Traumatologie - Sports Orthopaedics and Traumatology 2012;28:12-16.

40 Boostani MH, Erfani M, Boostani MA, et al. Sport injuries in karate competition. J Am Sci 2012;8:637-9.

41 Boostani M, Boostani M, Nowzari V. Type, incidence and causes of injuries in elective karate national team competition for dispatch to Asian karate Championship in Uzbekistan 2012. Journal of Combat Sports and Martial Arts 2012;3:43-5.

42 Arriaza $R$, Inman $D$, Arriaza $A$, et al. Low risk of injuries in young adolescents participating in top-level karate competition. Am J Sports Med 2016:44:305-8.

43 Čierna D, Lystad RP. Epidemiology of competition injuries in youth karate athletes: a prospective cohort study. Br J Sports Med 2017;51:1285-8.

44 Čierna D, Barrientos M, Agrasar C, et al. Epidemiology of injuries in juniors participating in top-level karate competition: a prospective cohort study. $\mathrm{Br}$ J Sports Med 2018;52:730-4

45 Antekolović L, Lenard M, Wertheimer V. Frequency and types of injuries in karate [Croatian]. Croatian Sports Medicine Journal 2016;31:58-63.

46 Arriaza Loureda R, Lopez Fernadez J. Karate [Spanish]. Archivos de Medicina del Deporte 1989;6:85-7

47 Birrer RB, Birrer CD. Martial arts injuries. Phys Sportsmed 1982;10:103-8.

48 Brettel HF. Injuries by karate blows [German]. Beitr Gerichtl Med 1981;39:87-90.

49 Coghlan J. Prevention of injuries in karate and other martial arts [Spanish]. Archivos de La Sociedad Chilena de Medicina del Deporte 1987:32:103-12.

50 Del Vecchio FB, Farias CB, de Leon RC, et al. Injuries in martial arts and combat sports: prevalence, characteristics and mechanisms. Sci Sports 2018;33:158-63.

51 Demorest RA, Koutures C, et al, COUNCIL ON SPORTS MEDICINE AND FITNESS. Youth participation and injury risk in martial arts. Pediatrics 2016;138:e20163022.

52 Destombe C, Lejeune L, Guillodo Y, et al. Incidence and nature of karate injuries. Joint Bone Spine 2006;73:182-8.

53 Ellapen TJ, Abrahams S, Desai FA, et al. Incidence of karate-related musculoskeletal pain among SKISA Karatekas. Af J Phys Health Edu Rec \& Dance 2011;17:103-11.

54 Greier K, Riechelmann H, Ziemska J. Sport injuries in full contact and semi-contact karate: (a comparison of kyokushinkai and traditional karate) [German]. Sportverletz Sportschaden 2014:28:31-5.

55 Kujala UM, Taimela S, Antti-Poika I, et al. Acute injuries in soccer, ice hockey, volleyball, basketball, judo, and karate: analysis of national registry data. $B M$ 1995;311:1465-8.

56 Kurland HL. Injuries in karate. Phys Sportsmed 1980;8:80-5.

57 McLatchie G. Karate and karate injuries. Br J Sports Med 1981;15:84-6.

58 McLatchie GR, Davies JE, Culley JH. Injuries in karate--a case for medical control. $J$ Trauma 1980:20:956-8.

59 Müller-Rath R, Bolte S, Petersen P, et al. [Injury profile in modern competitive karate-analysis of 1999 WKC-Karate World Championship Games in Bochum]. Sportverletz Sportschaden 2000;14:20-4.

60 Müller-Rath R, Miltner O, Mamarvar M, et al. Risk of injury in junior competitive karate [German]. Sportverletz Sportschaden 2005;19:191-4

61 Oler M, Tomson W, Pepe $\mathrm{H}$, et al. Morbidity and mortality in the martial arts: a warning. J Trauma 1991;31:251-3.

62 Pereira EM. Accidents and lesions typical of the practice of karate-do [Portuguese]. Medicina do Esporte 1975;2:163-4.

63 Pieter W. Time-loss injuries in karate. Acta Kinesiologiae Universitatis Tartuensis 2007;12:104-15.

64 Raschka C, Parzeller M, Banzer W. [15 years insurance statistics of incidents and accident types of combat sports injuries of the Rhineland-Pfalz Federal Sports Club] Sportverletz Sportschaden 1999;13:17-21.

65 Rosso C, Zenhausern R, Valderrabano V. Injuries in karate-like martial arts [German]. Schweizerische Zeitshrift fur Sportmedizin und Sporttraumatologie 2010;58:56-7.

66 Schmid P, Schwarz R. Karate and trauma [German]. Oesterreichisches Journal fuer Sportmedizin 1977;7:29-32.

67 Swanson J-D, Morrissey J, Barragan A. Comparison of Shotokan karate injuries against injuries in other martial arts and select NCAA contact sports. The Sport Journal 2017;19:3.

68 Tischer T, Lembcke B, Ellenrieder M, et al. [Injuries in Karate Sports: A Survey Performed During the World Championship 2014]. Sportverletz Sportschaden 2016:30:204-10

69 VencesBrito A, Castro MA, Valente EJ, et al. Is the Portuguese karate practice safe? Rev. artes marciales asiát. 2016:11:46-7.

70 CD W, Hang YS. Karate injuries. Journal of Surgical Association Republic of China 1993:26:1603-8.

71 Zakarian H, Commandre FA. Traumatic pathology of the karateka [French]. Medecine du Sport 1997:71:57-62.

72 Zetaruk MN, Violán MA, Zurakowski D, et al. Karate injuries in children and adolescents. Accid Anal Prev 2000;32:421-5.

73 Zetaruk MN, Violán MA, Zurakowski D, et al. Injuries in martial arts: a comparison of five styles. Br J Sports Med 2005;39:29-33.

74 Zetaruk MN, Zurakowski D, Violán MA, et al. Safety recommendations in Shotokan karate. Clin J Sport Med 2000;10:117-22. 
75 Ziaee V, Shobbar M, Lotfian S, et al. Sport injuries of karate during training: an epidemiologic study in Iran. Asian J Sports Med 2015;6:e26832.

76 James K. Incidence and severity of karate injuries: a comparison between genders and age categories [Dissertation. Cardiff, United Kingdom: University of Wales Institute Cardiff, 2008.

77 Sterkowicz S. Charakterystyka niektórych urazowych obrażeń ciała powstających $\mathrm{Na}$ zawodach karate. Zeszyty Naukowe AWF w Krakowie 1984;36:234-51.

78 Ghasemi GA, Marandi SM, Batavani M, et al. Incidence and mechanism of acute injuries in Iran karate Championship 2010. Br J Sports Med 2010;44:i6-7.

79 Lystad RP, Pollard H, Graham PL. Epidemiology of injuries in competition taekwondo: a meta-analysis of observational studies. J Sci Med Sport 2009;12:614-21.

80 Pocecco E, Ruedl G, Stankovic N, et al. Injuries in judo: a systematic literature review including suggestions for prevention. Br J Sports Med 2013;47:1139-43.

81 Thomas RE, Zamanpour K. Injuries in wrestling: systematic review. Phys Sportsmed 2018:46:168-96.

82 Lystad RP, Gregory K, Wilson J. The epidemiology of injuries in mixed martial arts: a systematic review and meta-analysis. Orthop I Sports Med 2014;2:2325967113518492.

83 Lystad RP. Injuries to professional and amateur kickboxing contestants: a 15-year retrospective cohort study. Orthop J Sports Med 2015;3:2325967115612416.
84 Tabben $M$, Coquart J, Chaabène $\mathrm{H}$, et al. Time-motion, tactical and technical analysis in top-level karatekas according to gender, match outcome and weight categories. J Sports Sci 2015;33:841-9.

85 Lystad RP. Epidemiology of injuries in full-contact combat sports. Australas Epidemiol 2015;22:14-18.

86 Schroll JB, Moustgaard R, Gøtzsche PC. Dealing with substantial heterogeneity in Cochrane reviews. Cross-sectional study. BMC Med Res Methodol 2011;11:22.

87 Peters JL, Sutton AJ, Jones DR, et al. Assessing publication bias in meta-analyses in the presence of between-study heterogeneity. J R Stat Soc Ser A Stat Soc 2010;173:575-91.

88 Bahr R, Clarsen B, Derman W, et al. International Olympic Committee consensus statement: methods for recording and reporting of epidemiological data on injury and illness in sport 2020 (including STROBE extension for sport injury and illness surveillance (STROBE-SIIS)). Br J Sports Med 2020;54:372-89.

89 Orchard JW, Meeuwisse W, Derman W, et al. Sport medicine diagnostic coding system (SMDCS) and the orchard sports injury and illness classification system (OSIICS): revised 2020 consensus versions. Br J Sports Med 2020;54:397-401. 